\title{
Frag-Virus: a new term to distinguish presumptive viruses known primarily from sequence data
} Alexander Voevodin*1 and Preston A Marx ${ }^{2}$

\author{
Address: ${ }^{1}$ Vir\&Gen, Toronto, Canada and ${ }^{2}$ Division of Microbiology, Tulane National Primate Research Center, Covington, Louisiana USA \\ Email: Alexander Voevodin* - voevodin@hotmail.com; Preston A Marx - pmarx@tulane.edu \\ * Corresponding author
}

Published: 27 February 2008

Virology Journal 2008, 5:34 doi:10.1 186/1743-422X-5-34

This article is available from: http://www.virologyj.com/content/5/I/34

(c) 2008 Voevodin and Marx; licensee BioMed Central Ltd.

This is an Open Access article distributed under the terms of the Creative Commons Attribution License (http://creativecommons.org/licenses/by/2.0), which permits unrestricted use, distribution, and reproduction in any medium, provided the original work is properly cited.
Received: 18 February 2008

Accepted: 27 February 2008
The wide availability of PCR-based methods for the amplification of nucleic acids homologous to known viral genomes plus automated DNA sequencing have led to explosive growth of a new field, 'proxy' virus isolation. Typically, genomic fragments are amplified and subjected to phylogenetic analysis showing that they are related to, but distinct from, known 'bona fide' viruses. These "new viruses" are now commonly reported in the virological literature and are too numerous to cite here, two studies are given as typical examples [1,2]. Although unintentional, these reports may, mislead the readership of scientific journals and the general press. Having no distinction between preliminary genome-based evidence and conclusive proof by biological isolation and characterization of a replication-competent virus blurs the meaning of new virus.

To distinguish presumptive viruses known primarily through genomic sequence fragments from bona fide viruses we propose the term 'frag-virus'.

The 'frag-virus status' may be intermediary between 'full' recognition as a new virus, as occurred, for example, with hepatitis C virus and Kaposi sarcoma herpesvirus [3-6]. Frag-virus designation may also be a category for such virus that likely exists, but there is neither sufficient motivation nor resources to pursue its elevation from frag-virus limbo to bona fide virus status. At the same time the fragvirus status will be a 'career end-point' for sequences belonging to non-infectious 'pseudo-viruses' or those having their origins in artifact.
Whatever the 'fate' of frag-viruses, this simple term is highly informative and may prove useful in preventing misconceptions about new viruses.

\section{References}

I. Keele BF, Van Heuverswyn F, Li Y, Bailes E, Takehisa J, Santiago ML, Bibollet-Ruche F, Chen Y, Wain LV, Liegeois F, Loul S, Ngole EM, Bienvenue Y, Delaporte E, Brookfield JF, Sharp PM, Shaw GM, Peeters $\mathrm{M}, \mathrm{Hahn} \mathrm{BH}$ : Chimpanzee reservoirs of pandemic and nonpandemic HIV-I. Science 2006, 3 I3:523-526.

2. Van Heuverswyn F, Li Y, Neel C, Bailes E, Keele BF, Liu W, Loul S, Butel C, Liegeois F, Bienvenue Y, Ngolle EM, Sharp PM, Shaw GM, Delaporte E, Hahn BH, Peeters M: Human immunodeficiency viruses: SIV infection in wild gorillas. Nature 2006, 444:164.

3. Choo QL, Kuo G, Weiner AJ, Overby LR, Bradley DW, Houghton M: Isolation of a cDNA clone derived from a blood-borne nonA, non-B viral hepatitis genome. Science 1989, 244:359-362.

4. Choo QL, Richman KH, Han JH, Berger K, Lee C, Dong C, Gallegos C, Coit D, Medina-Selby R, Barr PJ: Genetic organization and diversity of the hepatitis C virus. Proc Natl Acad Sci USA I99I, 88:245I-2455.

5. Chang Y, Cesarman E, Pessin MS, Lee F, Culpepper J, Knowles DM, Moore PS: Identification of herpesvirus-like DNA sequences in AIDS-associated Kaposi's sarcoma. Science 1994, 266: 1865-1869.

6. Russo JJ, Bohenzky RA, Chien MC, Chen J, Yan M, Maddalena D, Parry JP, Peruzzi D, Edelman IS, Chang Y, Moore PS: Nucleotide sequence of the Kaposi sarcoma-associated herpesvirus (HHV8). Proc Natl Acad Sci USA 1996, 93: |4862-I 4867. 